\title{
Cleidocranial Dysplasia - A Case Report
}

\author{
Displasia Cleidocraneal - Reporte de Caso
}

*Nilton Alves \& **:Reinaldo de Oliveira

\begin{abstract}
ALVES, N. \& OLIVEIRA, R. Cleidocranial dysplasia - A case report. Int. J. Morphol.,26(4):1065-1068, 2008.
SUMMARY: The cleidocranial dysplasia is a rare disease which can occur either spontaneously or by a dominant autosomal inheritance, with no predilection of genre or ethnic group. The odontologist is, most of the times, the first professional who patients look for to solve the problem, since there is a delay in the eruption and /or an absence of permanent teeth. In the case related in this work, this was the reason why the patient looked for treatment. Many others odontological problems are also present in this syndrome, such as, supernumerary teeth, retained teeth, with shape deviation and absence of deciduous teeth resorption. The premature diagnosis allows a proper orientation for the treatment, offering a better life quality for the patient.
\end{abstract}

KEY WORDS: Cleidocranial dysplasia; Dysostosis; Dentofacial deviation.

\section{INTRODUCTION}

The cleidocranial dysplasia, also known as Marie and Sainton Disease, Scheuthauer Marie-Sainton Syndrome and Mutational dysostosis (Shafer et al., 1979) is a rare disease which can occur either spontaneously or by a dominant autosomal inheritance, with no predilection of genre or ethnic group (Silva et al., 1995; Neville et al., 2004). It is characterized by a generalized skeletal dysplasia. The absence of the clavicles, which occurs in $10 \%$ of cases or the presence of hypoplastic clavicles allow the patient the movement of the shoulders up to the medial plan of the body without any discomfort.

These individuals are usually short. They have persistent fonticulus of the cranium or late closure of the same. The sutures can also remain opened, and the sagital suture presents itself depressed, giving the cranium a flat appearance. The parietal bones, frontal and occipital are proeminent, the paranasal sinus underdeveloped and many other cranial abnormalities might be present.

Regarding the manifestations of odontological interest it is important to mention that these patients show an arcate, narrow and deep palato. The maxilla can be underdeveloped and shorter than normal in relation to the mandible, resulting as a consequence, in a pseudo mandibular prognatism. The zygomatic and lacrimal bones can also present themselves underdeveloped. In the region of the sinphysis of the mandible an incomplete fusion is commom to be observed. Another important finding is the presence of supranumerary teeth, impacted and ectopic, presenting crown and root anomalies. The dental eruption is retarded, and an absence of root resorption in the deciduous teeth, hypodontia and dentigerous cysts can be observed.

We can also find an increase in the osseous density of some regions as a result of an abnormal remodeling of the bone, and the absence or less quantity of the cellular cementum in the roots of the permanent teeth (Rushton, 1956) and in some cases in both dentitions (Smith, 1968).

The therapeutic proposal for the alteration in the dentoalveolar complex, in the bearer of the cleidocranial dysplasia, involves the teeth restoration of the deciduous teeth when they present cavities, because their extraction does not necessarily induces the eruption of the permanent teeth (Shafer et al.). It also involves the orthognathic surgery, to fix the maxillary hypoplasia, and the surgery in the impacted teeth in association with the ortodontical and/ or prosthetic therapy. The implantodonty came out recently as another therapeutic option in the oral rehabilitation of these patients (Halazonetis \& Halazonetis, 1995; Becker et al., 1997; Lombardas \& Toothaker, 1997; Dawjee e Nkhumeleni, 2002). 


\section{CASE REPORT}

Female patient, melanoderm, 20 years and nine months old, was sent to the Centro de Imaginologia Papaiz e Associados for a panoramic radiography.

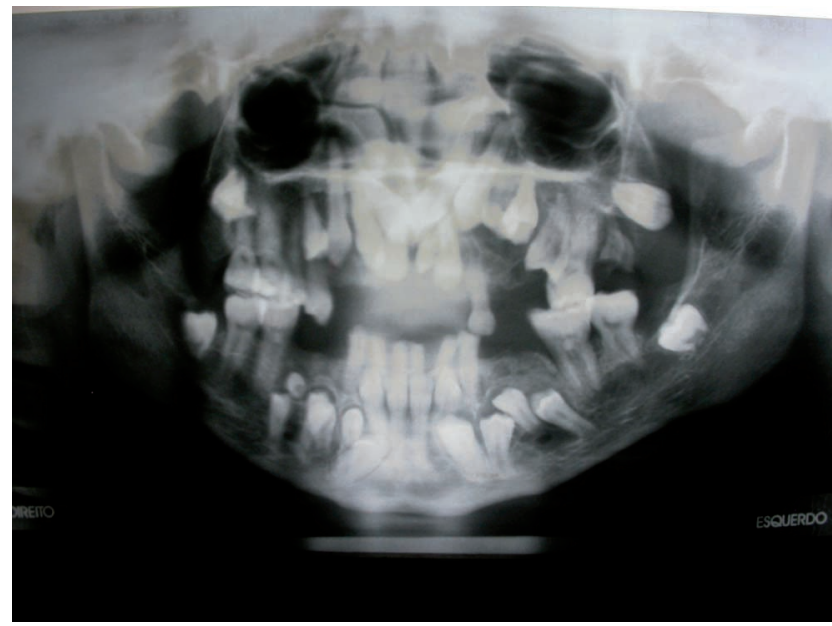

Fig. 1. Panoramic radiography that shows the existence of several dental elements retained and impacted in maxilla and mandible, supranumeric teeth and underdeveloped maxillary sinus.

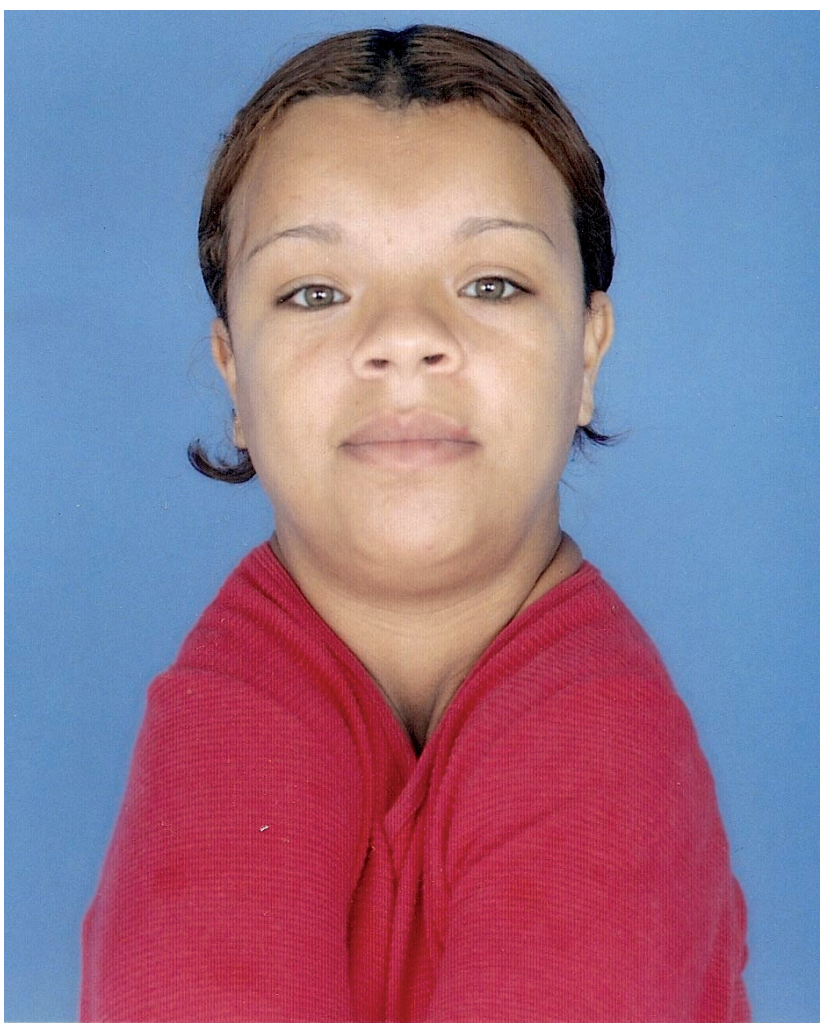

Fig. 2. Anterior view of the patient with cleidocranial dysplasia. Observe the proeminance of the frontal and parietal bones, determining the increase of the cranial perimeter.
During the anamnesis, the patient denied the existence of systemic or chronic diseases, as well as any alteration in internal organs. She also claimed not having direct ascendents or descendents who presented any physical or craniofacial abnormalities.

The radiographic shots revealed the existence of several dental elements retained and impacted in maxilla and mandible. It was also noticed the presence of supranumeric teeth and underdeveloped maxillary sinus (Fig. 1).

In the extra-oral physical examination we could notice short height, reduced inter acromial distance, proeminet frontal and parietal bones, determining an increase in the cranial perimeter (Fig. 2). When asked to move the shoulders, she was capable of bringing closer the humeral heads, which characterized the hipermobility of the shoulders (Fig. 3).

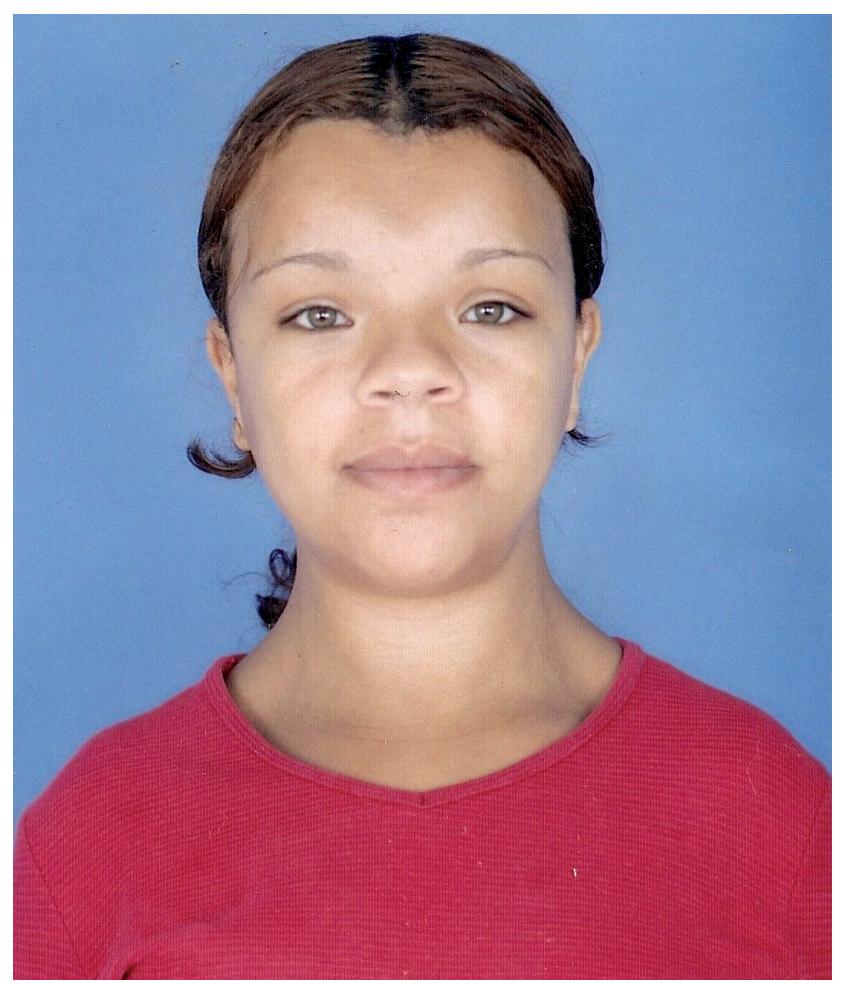

Fig. 3. Anterior view of the patient that shows the approximation of the humeral heads, which characterizes the hipermobility of the shoulders.

In the intra-physical examination it was clear the atresia of the maxilla, ogival and deep palatum, and also a mixed dentition.

According to the clinical and radiographical findings, the diagnosis was a cleidocranial dysplasia. 


\section{DISCUSSION}

This pathology was first described in 1765, whereas only in 1898 Marie \& Sainton had described cases of the disease and associated them with patterns of inheritance. Later, Bauer apud Kallialla (1962) suggested the genetic mutation as an etiological factor of the disease. In 1946 Lasker apud Forlan (1962) had concluded that is was a genetic disease with an autossomal dominant inheritance, and in some cases, external interferences in the fetal period could cause this mutation that is transferred to the progeny.

In our case, the patient did not report the existence of direct ancestors or descendents who presented any clinical characteristic of cleidocranial dysplasia. She was alerted of the inheritance characteristic of the disease and also about the genetic counseling.

The radiographic characteristic allowed us to notice the presence of the permanent teeth germs, the temporary teeth was still in the dental arcade, although the patient was in her second decade of life. It could also be observed an enormous quantity of supranumeric teeth.

The feilure in the eruption can be related with the absence or less amount of cellular cementum in the permanent teeth roots (Rushton). This was also claimed by Smith, who had observed the absence of cellular cementum in the deciduous and permanent dentition. There are also other hypothesis that explain this fact, as the lack of absorption of the deciduous teeth and subjacent bone and also the presence of a physical barrier, represented by the supranumeric teeth impacted or by a fibrous connective tissue interposed between the dental folliculus and the mucosa.

The delay in the eruption and the absence of permanent teeth, observed in our case, was responsible for a strong sentiment of sadness from the patient, what led her to look for treatment.

Although several bones in the body could present the cleidocranial dysplasia, the craniofacial characteristics consists of the main reason of the medical-odontological visits to the doctor. That is why the odontologist is so important in the diagnosis of this condition, as well as in the implementation of a therapeutic multidisciplinary planning, aiming the improvement in the life quality of the patients.

ALVES, N. \& OLIVEIRA, R. Dispasia cleidocraneal - Reporte de caso. Int. J. Morphol.,26(4):1065-1068, 2008.

RESUMEN: La displasia cleidocranial es una enfermedad rara que puede ocurrir, ya sea espontáneamente, o por una herencia autosómica dominante, sin predilección de género o grupo étnico. El odontólogo, en la mayoría de las veces, es el primer profesional que buscan los pacientes para resolver el problema, ya que hay un retraso en la erupción y/o ausencia de dientes permanentes. En el caso presentado en este trabajo, ésta fue la razón por la que el paciente esperó para recibir tratamiento. Muchos otros problemas odontológicos están también presentes en este síndrome, como por ejemplo, dientes supernumerarios, dientes retenidos, con desviación de la forma y la resorción y ausencia de dientes temporales. El diagnóstico precoz permite una adecuada orientación para el tratamiento, ofreciendo una mejor calidad de vida para el paciente.

PALABRAS CLAVE: Displasia cleidocraneal; Disostosis; Desviación dentofacial.

\section{REFERENCES}

Becker, A.; Lustmann, J. \& Shteyer, A. Cleidocranial dysplasia: Part 1--General principles of the orthodontic and surgical treatment modality. Am. J. Orthod. Dentofacial Orthop., 111(1):28-33, 1997.

Dawjee, S. M. \& Nkhumeleni, F. Cleidocranial dysplasia-a case report. SADJ, 57(5):187-90, 2002.

Forlan, M. Cleidocranial dysostosis. Am. J. Med., 33(2):7929, 1962.
Halazonetis, J. \& Halazonetis, D. J. Autotransplantation in cleidocranial dysplasia: case repor with 5-year follow up. J. Oral Maxillofac. Surg., 53(12):1472-5, 1995.

Kallialla, E. \& Taskinen, P. J. Cleidocranial dysostosis. Oral Surg., 15(8):808-22, 1962.

Lombardas, P. \& Toothaker, R.W. Bone grafting and osseointegrated implants in the treatment of cleidocranial dysplasia. Compend. Contin. Educ. Dent., 18(5):509-12, 1997. 
Marie, P. \& Sainton, P. Sur la dysostose cleido-cranienne héréditaire. Rev. Neur., 6:835-8, 1898.

Neville, B. W.; Damm, D. D.; Allen, C. M. \& Bouquot, JE. Patologia oral e maxilofacial. 2a . ed Rio de Janeiro, Guanabara Koogan, 2004.

Rushton, M. A. An anomaly of cementum in cleidocranial dysostosis. Br. Dent. J., 100:81, 1956.

Silva, J. J.; Costa, R. R.; Silva, M. C. A.; Henriqson, D. \& Stêvão, E. L. L. Disostose cleidocraniana: relato de caso clínico. Rev. Odonto Ciência, 24:209-14, 1995.

Shafer, W. G.; Hine, M. K. \& Levy, B. M. Patologia bucal. $1^{\mathrm{a}}$. ed., Rio de Janeiro, Interamericana, 1979.

Shaikh, R. \& Shusterman, S. Delayed dental maturation in cleidocranial dysplasia. ASDC J. Dent. Child., 5:325-9, 1998.

Smith, N.H.H. A histologic study of cemetum in a case of cleidocranial dysostosis. Oral Surg.; 25:470, 1968.
Correspondence to:

Prof. Dr. Nilton Alves

Av. Onze de Junho, 643 Apto. 174

CEP 04041-052

Vila Clementino

São Paulo - SP

Brasil

Email: niltonnalves@hotmail.com

Received: 25-01-2008

Accepted: 23-09-2008 